\title{
Womens' Empowerment Program to Develop the Potential of Entrepreneurship
}

\author{
Lilis Karwati \\ Department Non-formal Education, Universitas Pendidikan Indonesia \\ Jl. Dr. Setiabudhi 229 Bandung 40154, Indonesia \\ lilis .karwati03@gmail.com
}

\begin{abstract}
The potential of women in public life still has not received a reasonable portion. This needs to be addressed wisely by the government in view of women in terms of quantity ranks first on the composition of the community. The empowerment of women through education and skills program aimed at increasing the capacity of women to participate and contribute in improving prosperity required to participate in improving their self-esteem, family and community in supporting the sustainable development of socio-economic field better through entrepreneurship training. The empowerment of women through education programs based entrepreneurial skills through a qualitative approach and descriptive method. The concept of empowerment is an attempt to make something that is fair and civilized become more effective in all aspects of life. Empowering women to improve their skills and life skills for women so that they can be empowered and able to take advantage of its potential. Results showed that the ability to obtain the educational skills were able to make their opportunities for entrepreneurship in improving their quality of life and affects the independence of women at the level of socioeconomic better, through empowerment-based women's entrepreneurship can play a role in public life, especially to help improve the status and needs of the family.
\end{abstract}

\section{Keywords - Women's empowerment-based entrepreneurship}

\section{INTRODUCTION}

Development of entrepreneurship is an important link for the empowerment of women to the nation's economic growth and have a positive impact in improving the ability of skills and expertise in developing entrepreneurship which will support the advancement of economic development, in an environment where the people are [11]. Entrepreneurial activity helps in creating wealth with wealth and reduce unemployment, to enhance the knowledge and skills and insights in increasing total production (GDP) of a nation, and create jobs and innovation, women's participation in increasing the revenue is very influential on the role of the position of women is very important for socio-economic development as a whole for the entire developing world as well as the state of Indonesia, because it helps women to enter the market opportunities in developing the activities of entrepreneurial profit and advantage in sustaining the family needs a brand, it will provide insight into the extent to which these properties can be developed through education, skills training, or a learning experience, a person can be motivated for their demands to get a position of authority, affiliation, and achievement [12].
The need for achievement is the hope in the desired order to have the prestige of the social status of the environment of communities change attitudes and behavior as encouragement to excel and strive for success in the future in continuing life [13]. Through the skills needed to decide, choose to identify needs and take advantage of opportunities and possibilities in entrepreneurial activity that depends on the level of exploitation of entrepreneurship, knowledge of educational skills they have acquired through the acquisition of skills, experience and social networks in conducting business activities $[11,14,15]$,

Entrepreneurship has the character attributes that need to be owned by women so as to enhance the independence of trying to be reached among them self-confidence [16], selfconfidence, perseverance, action orientation, entrepreneurial skills as the efforts to solve the problems faced in addressing the needs and demands creatively, but must have the ability to communicate in persuading, negotiating, and have the strategic thinking and social networks used in business activity. [17] In the exercise of entrepreneurial activity should be able to give confidence to the business activities conducted by the discovery and development as well as that in stimulating entrepreneurial activity, through education, knowledge skills with creativity and innovation has a critical and reflective thinking in developing the practice of business activities. [18] Highlighting the importance of motivation, self-confidence and "I can do" attitude as the basis for becoming self-employed people who have principles that we ourselves can do activities like other people through education and practice of conducting business. Approach to developing entrepreneurial activity can be carried environment communities to change attitudes and life as encouragement to excel and strive for success in the future in continuing life [13]. Through the skills needed to decide, choose to identify needs and take advantage of opportunities and possibilities in entrepreneurial activity that depends on the level of exploitation of entrepreneurship, knowledge of educational skills they have acquired through the acquisition of skills, experience and social networks in conducting business activities $[11,14,15]$,

[16] Entrepreneurship has character attributes that need to be owned by women so as to enhance the independence of trying to be reached among them self-confidence, selfconfidence, perseverance, action orientation, entrepreneurial skills as the efforts to solve the problems faced in addressing the needs and demands creative, but must have the ability to communicate in persuading, negotiating, and have the strategic thinking and social networks used in business activity. [17] In 
the exercise of entrepreneurial activity should be able to give confidence to the business activities conducted by the discovery and development as well as that in stimulating entrepreneurial activity, through education, knowledge skills with creativity and innovation has a critical and reflective thinking in developing the practice of business activities. [18] Highlighting the importance of motivation, self-confidence and "I can do" attitude as the basis for becoming self-employed people who have principles that we ourselves can do activities like other people through education and practice of conducting business. Approach to developing entrepreneurial activity can be carried on the practice and development activity they pursue their own efforts in their everyday environment [19]. Entrepreneurship can be considered as a mindset or process reflects that mind-set that can create, improve, develop economic activities in fostering innovation, creativity, courage to take risks, and be of good management in improving the skills [20].

[21] In essence, by increasing entrepreneurial activity based on one individual among women can be involved in entrepreneurial ventures in order to avoid unemployment or poverty, or to increase revenue as well as the opportunity to take advantage of opportunities in profit. [22] Where entrepreneurship is increasingly being recognized by the government as an effective tool in creating jobs to improve productivity and competitiveness in improving the quality of life to achieve public welfare goals [24]. Some experts believe that women have a strong character diligent and trustworthy in carrying out business activities when it has autonomy in operations to improve the economic status promote geopolitical stability and peace in the world (Forbes) [25].

In the implementation of the empowerment of women entrepreneurship based position of family and social obstacles to be overcome before establishing themselves as an independent entrepreneur in the sense of belief and mental ability held in pioneering business activity [26]. In the entrepreneurial activities in empowering women in conducting business as their career, not only to benefit and achieve goals to improve the well-being, but at the same time they are also indulge in the power of the organization in their position in society or to bring about change social status that has the same rights and obligations in social status. In short, they signify that women are not marginalized, so that women can live independently [27].

\section{METHOD}

The method used in this research is descriptive method to assess the problems that occur in the vocational education program at this time, the impact of women's empowerment program based entrepreneurship through collection techniques

- Interviews. Conducted on: (1) the learners, to determine the success and impact of the empowerment of women through education programs in entrepreneurship skills for learners. (2) Tutor, for processes, approaches, methods and learning techniques are used. (3) business, the activity is performed to determine the processes and strategies and the level of achievement of the objectives of program management performed.
- Observes and observations. This technique is used to assess the circumstances and the process of implementation of the program.

- Study documentation and literature, this activity is conducted to assess the implementation of the program in writing, photos of activities, and documents as well as the suitability of the theory related to the program.

From the information obtained through observation and interview, after participating in learning activities of vocational education there is a change in self-learners. These changes can be seen from three aspects: cognitive, affective and psychomotor. Based on the interview changes seen on the ability of citizens to learn increases. Conditions did not initially have any skill ability, finally after joining a study program that has the ability and the skills people learn that everything is successfully empowered women characterized by proficient producing goods. The impact of the implementation of the empowerment of women is the increased revenue that had not been previously they get with the aim of improving the quality of life and improve their lives.

\section{DISCUSSION}

$S$ Based on interviews with informants about the process of empowerment of women through education-based entrepreneurial skills as follows.

Questions were asked of the informant is associated with a). The background of the implementation of the empowerment of women through education-based entrepreneurial skills, b). The process of implementation of the empowerment of women through education-based skills c). factors driving and inhibiting the process of empowerment of women through education skills in Ciamis, West Java Indonesia Questions were addressed to the organizers. The results of the interview can be seen in the following table:

TABLE I. INTERVIEW RESULT

\begin{tabular}{|c|l|l|}
\hline \multicolumn{1}{|c|}{ Source } & $\begin{array}{l}\text { Processes and } \\
\text { Questions }\end{array}$ & \multicolumn{1}{c|}{ informant } \\
\hline Board 1 (P1) & $\begin{array}{l}\text { 1) Planning and } \\
\text { implementation } \\
\text { of education } \\
\text { programs based } \\
\text { entrepreneurial } \\
\text { skills: } \\
\text { background for } \\
\text { convening skills } \\
\text { education } \\
\text { program? } \\
\begin{array}{l}\text { 3) How is the } \\
\text { process of } \\
\text { implementation } \\
\text { of the } \\
\text { empowerment of } \\
\text { women through } \\
\text { education skills? }\end{array}\end{array}$ & $\begin{array}{l}\text { 1) Informant 1 was the organizer } \\
\text { (P1) said that the background of } \\
\text { the convening of vocational } \\
\text { education Program,Informant 1 } \\
\text { was the organizer (P1) said that } \\
\text { the background of the education } \\
\text { grant program making skills } \\
\text { snacks. Middle and lower } \\
\text { economic strata circumstances, } \\
\text { the head of the household on } \\
\text { average only have a job as a } \\
\text { laborer his wife did not work, as a } \\
\text { housewife. } \\
\text { 2) Based on the above problems, } \\
\text { to help do not have enough } \\
\text { education and skills of the } \\
\text { mothers whose numbers 20 } \\
\text { people nurtured and empowered, }\end{array}$ \\
\hline
\end{tabular}


Table I, cont.

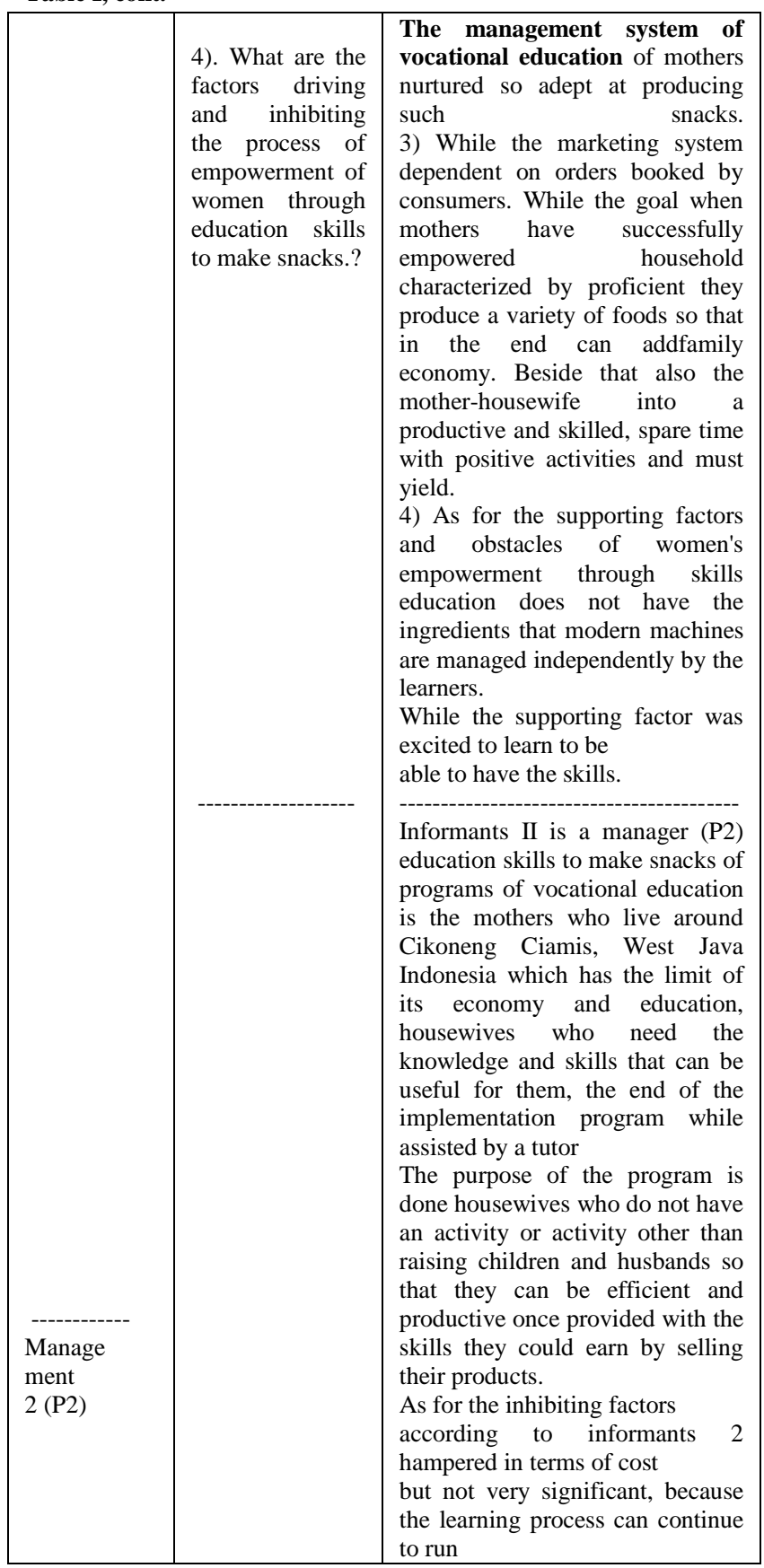

The educational program making skills snacks motivated by the needs of the community. The state of society mostly in the middle and lower economic strata, the head of the household on average only have a job as a laborer, while the wife does not work, they are just as housewives who are not productive. The housewives are only educated up to primary school and do not have the expertise skills, therefore, based on the problems that are there to help and empower the housewives who do not have enough education and skills of the organizers and administrators PKBM District of Cikoneng establish education programs skill In the process of implementation of vocational education, the first time the board invites the mothers around the area that is based on the existing problems in the field requires knowledge and skills that can make mothers are more productive, and it happened to community education program making skills snacks entrepreneurship based planning that is determine the components of the start learners, learning resources, learning materials, cost allocation and implementation time and set goals.

Based on observations and interviews conducted by investigators in the planning process that the manager did not identify the needs to the participants, the manager immediately presented educational programs the skills to make snacks with the aim to earn money to help his family's economy, these mothers were enthusiastic in participating in education skills they are empowered to be self-employed so that not only gain the skills people learn can earn revenue by developing skills in improving independence

\section{CONCLUSION}

Women's empowerment-based entrepreneurship as a means to help find their own solutions, enabling women to gain autonomy and has the potential to provide economic opportunities in control of their lives and entering the public domain with the skills and confidence so as to improve the economic and social status of their health and engage them in development activities. entrepreneurship development for women's empowerment had a positive impact as their career to the overall economic growth in economic development, not only women benefit and achieve the goal of improving the welfare of all people and to lift households out of poverty

\section{REFERENCES}

[1] Yabrifa Bumein and Comfort E. Mbach. (2014), Creativity and Innovation for Women Empowerment in Nigeria " Journal of Education, Arts and Sciences | Vol. 1, No. 3 ,pp 2362-8022

[2] Mbachu, C.E. \&Diepiribo, D.A.T, (2013) Developing functiona educational Programmes for the transformation of the girl-child. Journal of national association of female teachers (JONAFET) VOL 4 PP 43-4.

[3] Braide, E. (2006) Education of the girl Child in Nigeria: An unfinished business. A paper presented at the 1st international conference on empowering of the girl-child in science and technology through role modeling organized by forum for African women educationalists held in Adekunle Ajasin university, Akungba- Akoko, Onde State. 29th Aug. pp. 39-44.

[4] Daraka Chhay.(2011) "Women's economic empowerment through microfinance in Cambodia" Journal Development in Practice, Volume 21 Number 8,pp. 0961-4524.

[5] Ramaiah. Kollapudi, Nagamani.K, Latchaiah.P, Kishore.Mendam.(2015), "A Review on Dalith Women Empowerment in India", Journal of Education and Practice Vol.6, No.31,pp.. 2222-1735

[6] Floro, M., \& Wolf, J. M. (1990). The economic and social impacts of girls primary education: Advancingbasic education and literacy. ABEL project, Washington DC: USAID $\backslash$

[7] Anne Syomwene and Jonah Nyaga Kindiki. (2015)," Women Education and Economic Development in Kenya Implications for Curriculum Development and Implementation Processes", Journal of Education and Practice Vol.6, No.15,pp. 2222- 1735 
[8] Okeem, E. O. (1998). Towards assessing the impact of literacy education in therole of the Nigerian woman in development. In $\mathbf{M}$. Omolewa, E. E. Osuji, \& A. Oduaran (Eds.), Retrospect and renewal: The state of adulteducation research in Africa (pp. 251 - 256). Dakar, Senegal: UNESCO-BREDA

[9] Emmanuel U. Ingwu1 \& Stella-Maris A Okey.(2013)," Entrepreneurial Trainin Needs of Illiterate Women in Cross River State, Nigeria”. Journal International EducationStudies; Vol. 6, No. 11,pp.1913-9020

[10] Schultz, P. T. (1989). Benefits of educating women. World Background Paper Series, Education and Employment Division Population and Human Resources Department, Washington,D.C.

[11] Shane, S. 2003. A General Theory of Entrepreneurship: The Individual- opportunity Nexus Cheltenham: Edward Elgar.

[12] Abdullah Al Mamun \& Isidore Ekpe (2016) Entrepreneurial traitsand micro enterprise performance: a study among women microentrepreneurs in Malaysia, Development in Practice, 26:2, 193-202

[13] McClelland, D. 1988. Human Motivatio Cambridge: Cambridge University Press.

[14] Gibb, A. (2005), "The future of entrepreneurship education determining the basis for coherent policy and practice?", in Kyrö, P. and Carrier, C. (Eds), The Dynamics of Learning Entrepreneurship in a Cross-Cultural University Context, Entrepreneurship Education Series 2005/2, Research Centre for Vocational and Professional Education, University of Tampere, Hämeenlinna, pp. 44-67.

[15] Politis, D. (2005), "The process of entrepreneurial learning: a conceptual framework", Entrepreneurship Theory and Practice, Vol. 29 No. 4, pp 399424.
[16] Carsrud, A. and Brännback, M. (2011), "Entrepreneurial motivations: what do we still need t0 know?", Journal of Small Business Management, Vol. 49 No. 1, pp. 9-26.

[17] [Lenita Hietanen , (2015),"Facilitating employees' and students process towards nascent entrepreneurship", Education + Training, Vol. 57 Iss $8 / 9$ pp. $964-976$.

[18] OECD (2004),"Promoting Entrepreneurship and innovative SMEs in a global economy: towards a more responsible and inclusive globalisation", 2nd OECD Conference of Ministers Responsible for Small and Medium-Sized Enterprises (SMEs), Promoting Entrepreneurship and Innovative SMEs in a Global Economy: Towards a MoreResponsible and Inclusive Globalization, Istanbul, 3-5 June.

[19] Kelley, D.J., Singer, S. and Herrington, M. (2012), "Thegloba entrepreneurship monitor", 2011 Global Report, GEM 2011, pp. -37.

[20] Rakesh Belwal Hanan Al Balushi Shweta Belwal, (2015),"Students' perception of entrepreneurship and enterprise education in Oman", Education + Training, Vol. 57 Iss 8/9 pp. $924-947$

[21] Vinze, M. D. (1987). Women Entrepreneurs in India. New Delhi: Mitta Publications.

[22] Durva Shastria , Prof. U. T. Rao..(2014)..” Women Entrepreneurs of Gujarat". Procedia Economics and inance 11, pp. $745-752$ 